Association for Information Systems

AIS Electronic Library (AISeL)

Wirtschaftsinformatik 2021 Proceedings

Track 20: Management of digital processes \& architectures

\title{
BPM Capability Configuration in Times of Crises: How to Adapt Processes when the Virus strikes?
}

Vincent Borghoff

Fachhochschule Südwestfalen

Ralf Plattfaut

Fachhochschule Südwestfalen

Follow this and additional works at: https://aisel.aisnet.org/wi2021

Borghoff, Vincent and Plattfaut, Ralf, "BPM Capability Configuration in Times of Crises: How to Adapt Processes when the Virus strikes?" (2021). Wirtschaftsinformatik 2021 Proceedings. 4.

https://aisel.aisnet.org/wi2021/EManagementofdigitalprocesses20/Track20/4

This material is brought to you by the Wirtschaftsinformatik at AIS Electronic Library (AISeL). It has been accepted for inclusion in Wirtschaftsinformatik 2021 Proceedings by an authorized administrator of AIS Electronic Library (AISeL). For more information, please contact elibrary@aisnet.org. 


\title{
BPM Capability Configuration in Times of Crises: How to Adapt Processes when the Virus strikes?
}

\author{
Vincent Borghoff ${ }^{1}$, Ralf Plattfaut ${ }^{1}$ \\ ${ }^{1}$ South Westphalia University of Applied Sciences, Process Innovation \& Automation Lab, \\ Soest, Germany \\ \{borghoff.vincent,plattfaut.ralf\}@fh-swf.de
}

\begin{abstract}
With the impact of the Covid-19 pandemic, multiple organizations are experiencing cuts and changes in existing business concepts and face the challenge of adapting to the new circumstances. This short paper discusses preliminary results of a mixed methods based study on business process management capabilities. Using an existing BPM capability framework, we aim to show which configuration of BPM capabilities facilitates organizational survival and processual sustainment during crisis and contribute to both BPM theory and practice.
\end{abstract}

Keywords: Business Process Management, Covid-19, BPM Capabilities

\section{Introduction}

The Covid-19 crisis has not only changed personal and societal life, it directly affected whole economies as well as individual organizations as it made existing value propositions obsolete and established working routines no longer applicable [1]. In addition, governmental restrictions, as a response to a deepening pandemic, induced a high level of uncertainty into the economic environment [2]. This also manifests on process level, e.g. as social distancing makes an attendance based work culture impossible and forces organizations to quickly adapt and at the same time sustain quality. Organizations differ in their success in adapting to this fast market and environmental changes and their capability to align their business processes.

Business Process Management (BPM) can provide methods and approaches to meet the requirements of the new situation, as it is concerned with managing processes and both internal and external change induced through process drift and exogenous shocks. BPM capabilities depict the ability to successfully develop, monitor and adapt business processes within and between organizations., hence different configurations of those capabilities, inter alia, can form an organizations ability to sustain its business performance throughout a crisis. BPM capabilities in stable and incrementally changing environments are well understood [3-5], whereas there is a lack of insight for exogenous shocks like the Covid-19 crisis. Although there is literature on developing resilience against turbulent environments through BPM [6,7], there is no specific research concerning required capability configurations. 
Against this background the presented research-in-progress explores the following research question: Which configuration of BPM capabilities enables the utmost process performance within the context of a crisis?

The remainder of this short paper structures as follows: Section 2 provides background on BPM and the impact of Covid-19 on business processes. In Section 3 the planned research approach is presented, before Section 4 points out preliminary results of the study. The paper ends with a concluding discussion in Section 5.

\section{Background}

\subsection{Business Process Management}

BPM in general tries to ensure consistent outcomes of work and the exploitation of opportunities to improve, by investigating and monitoring how work is performed [8, 9]. It contributes both on overarching (e.g. process culture) and single process level (e.g. process implementation and monitoring) management within process oriented organizations $[10,11]$. Through this comprehensive nature, BPM can contribute to overall business success by offering methods and tools for structured process handling [12]. BPM is commonly structured along capability frameworks. One, broadly consented, framework is by de Bruin and Rosemann [13], which has been the basis for multiple studies in the field of BPM $[14,15]$. It structures BPM capabilities along the six core elements Strategic alignment, Governance, Methods, Information Technology, People and Culture. The implementation and institutionalization of the included 30 capabilities promotes and enables successful process orientation and therefore efficient business processes [16], as they map both the potential for incremental and radical process change [17, 18] as well as stable business processes [19].

\subsection{Covid-19 and impact on Business Processes}

Covid-19, as a globally spreading pandemic, acts like an exogenous shock to businesses all over the world [20]. These shocks are of extreme, unexpected, or unpredictable nature, as they force organizations to quickly respond to their impact [21]. This response involves the adaption of strategies, business logic and business processes to the new circumstances [22]. As existing strategies may become obsolete, even for whole business sectors and within complete value chains [23, 24], upstream and downstream processes, in addition to purely internal ones, must be adapted, e.g. the increase in remote work requires new process models and generates an ascent in IT based workflows to maintain operations [25, 26]. BPM can contribute on the one hand in creating resilient business processes, that are not affected through external and exogenous changes [27], or by fostering agile process adaption and alternation to quickly avoid cuts in efficiency or even exploit emerging opportunities [28]. The best suitable configuration of BPM capabilities for each of these contributions has so far been an underexplored chain within BPM research. While there is knowledge of the 
methods required for both orientations, there is a lack of insight into the necessary organizational capabilities.

\section{3 (Planned) Research Approach}

For our research we follow a sequential, developmental, mixed methods approach (Figure 1), combining qualitative and quantitative research [29, 30]. On a qualitative theory building phase, follows a quantitative theory testing phase [31]. We focus on the interplay between BPM capability configurations and business performance and sustainment on the background of an external crisis.
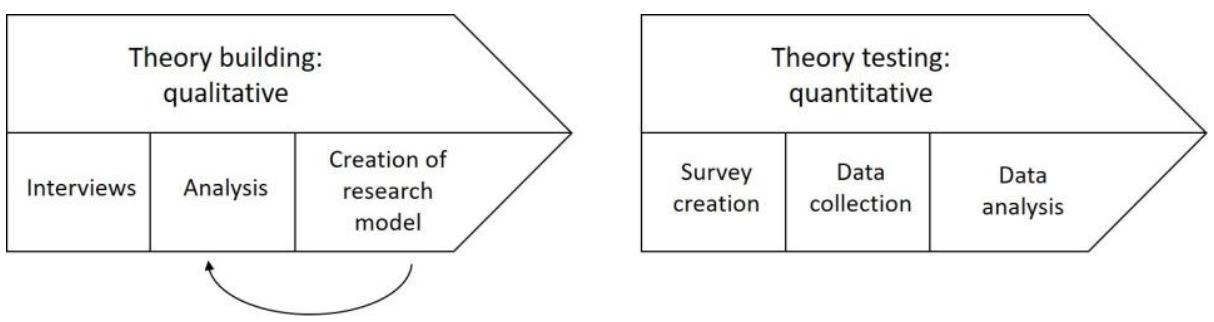

Figure 1. Schematic depiction of the used research approach

\subsection{Qualitative Phase: Theory building}

The qualitative phase aims at developing hypotheses as a basis for further research. For that purpose, we conducted five semi-structured interview with practitioners concerning the impact of the Covid-19 crisis on their organization and their BPM organizational BPM capabilities. All cases were chosen purposive, to achieve a sample of relevant experts and organizations of different sizes, sectors and legal structures [32]. The interview guideline was structured along the BPM core elements framework to determine the state of each core element within each case organization. The process performance prior to and within the crisis, as well as changes induced by the crisis, were specifically addressed. The interviews were transcribed, structured and coded [33], following the BPM core elements and capability areas as a research lens. We identify organizational requirements and actions regarding their representability within the framework and map each aspect to the respective capability area. This should give a first impression of the individual influence of single elements on the overreaching organizational BPM success. We include considerations about the status of each capability, meaning if one specific capability was existent prior to the crisis or developed in course of it. We iterate this process over all transcripts to develop consistent hypotheses and research models as a basis for the following phase [34]. 


\subsection{Quantitative Phase: Theory testing}

Based on the qualitative phase we plan to develop a comprehensive survey to test our hypotheses. Therefore we conceptualize our preliminary findings, as well as the BPM capability framework, and process them into a survey with the purpose to verify and generalize our former findings [35]. To reach that goal, we aim at building a measurement model to test the influence of the conceptualized BPM capability areas, as well as a set of context variables, against pre- and in-crisis process performance [36]. For modeling we use a systematic approach utilizing structural equation modeling [37]. We utilize core themes for each capability area from out the literature to make individual configurations measureable. This process is conducted via a systematic literature review. Subsequent to design and pilot testing, the final survey will be sent out and later statistically analyzed [38].

\section{Preliminary Results of First Case Interview}

Due the ongoing research process, in the following we present our preliminary results, originating from a first interview with the head of human resources of a larger mediumsized manufacturing company, representing findings concerning Covid-19 impact, BPM capabilities, as well as process and organizational change. The data from remaining interviews are currently being evaluated.

Streamlined, agile governance structures. First and foremost, the organization adapted its decision-making processes to the new circumstances. A massive shortening and streamlining of the decision-making structures led to faster adaptation cycles. This gives first hints on how governance-related BPM capabilities need to be configured, highlighting the importance of pace in decision making which is strongly influenced by clearly defined and executed government processes, given in the CE (core element) "process management decision making".

Shortened strategical planning cycles. Due to the large amount of uncertainty, the organization was forced to shorten their strategic scope. Long-term planning is postponed and processes need to align in short notice, which directly affects the strategic alignment core factor, specifically the bidirectional linkage between the overarching organizational strategy and the operated business processes. The organization switched from stable, long running processes to a more flexible process understanding, reweighting the strategic alignment in the short term.

Increased pace and willingness to digitalize. Prior the pandemic the internal drive towards digitalization and the conducted effort towards that goal was seen considerably low, resulting in equally low IT related BPM capabilities. With the changed conditions and need for remote work for a significant part of the workforce, digitalization became a main challenge, which takes up larger parts of the planning and development capacities. Whereas remote IT solutions became a big part of consideration, improvements considering BPM related IT were not part of the organizations efforts.

Shift to a more change-open culture. The organization observed a shift of culture towards a more change-open state. Where in the past deviations from routine were considered more as a burden and risk than an opportunity, impeding process change, 
within the crisis this attitude decreased, reflecting a change in capabilities within the core factor culture, especially concerning the "responsiveness to process change" capability, perceiving change as a potential opportunity.

Employee centricity. The aforementioned development is accompanied with a more comprehensive employee centricity. The organization stated that with the beginning of the crisis all organizational- and process related changes were adopted by a committee consisting of management and affected employees. The effects and the specific backgrounds were clearly communicated to the workforce. This allowed, as stated, frictionless and broadly accepted process change and emphasizes the importance of the core element people and especially the associated capability area "process collaboration and communication".

\section{$5 \quad$ Concluding Discussion}

The preliminary results show that the studied organization is developing towards more agile and therefore more adaptive processes than fostering resilience. This requires capabilities, especially in the area of digital competence, which were previously lacking and are currently being increasingly developed. These rapid, radical changes require clear and integrative decision making and communication in order to implement them, despite an observable change towards an open change culture. This can have a positive influence on the future retention and enhancement of the implemented agile process culture. The crisis can thus also be used as an opportunity to move towards a more agile and more digital way of working, enabling the organization to modernize at a rapid pace and break up existing structures. The faster changing strategic planning may become a risk, as process improvement is made more difficult by volatile conditions.

By means of these and the results of the analysis of the further qualitative data, we plan to achieve a deeper understanding of appropriate organizational capability configurations, which we plan to quantitatively verify in a further step. In addition to the Covid-19 pandemic, the research horizon can be extended and generalized to other exogenous shocks, as the requirements on a capability level are comparable.

The results are limited by the amount of qualitative data analyzed, so generalizability has to be discussed. We hope to overcome this limitation with the conduction of the planned quantitative study.

\section{References}

1. Verma, S., Gustafsson, A.: Investigating the emerging COVID-19 research trends in the field of business and management: A bibliometric analysis approach. Journal of Business Research 118, 253-261 (2020)

2. Baker, S., Bloom, N., Davis, S., Terry, S.: COVID-Induced Economic Uncertainty. National Bureau of Economic Research, Cambridge, MA (2020)

3. Vom Brocke, J., Rosemann, M. (eds.): Handbook on Business Process Management 1. Introduction, Methods, and Information Systems. Springer Berlin Heidelberg, Berlin, Heidelberg, s.l. (2015) 
4. Poeppelbuss, J., Plattfaut, R., Niehaves, B.: How Do We Progress? An Exploration of Alternate Explanations for BPM Capability Development. CAIS $36(2015)$

5. van Looy, A.: Capabilities for managing business processes: a measurement instrument. Business Process Mgmt Journal 26, 287-311 (2020)

6. Trkman, P., McCormack, K.: Supply chain risk in turbulent environments-A conceptual model for managing supply chain network risk. International Journal of Production Economics 119, 247-258 (2009)

7. Antunes, P., Mourão, H.: Resilient Business Process Management: Framework and services. Expert Systems with Applications 38, 1241-1254 (2011)

8. Dumas, M., La Rosa, M., Mendling, J., Reijers, H.A.: Fundamentals of Business Process Management. Springer Berlin Heidelberg, Berlin, Heidelberg (2018)

9. van der Aalst, W.M.P.: Business Process Management: A Comprehensive Survey. ISRN Software Engineering 2013, 1-37 (2013)

10. Bruin, T. de, Doebeli, G.: An Organizational Approach to BPM: The Experience of an Australian Transport Provider. In: Vom Brocke, J., Rosemann, M. (eds.) Handbook on Business Process Management 2. Strategic Alignment, Governance, People and Culture, pp. 741-759. Springer Berlin Heidelberg, Berlin, Heidelberg, s.l. (2015)

11. Vom Brocke, J., Zelt, S., Schmiedel, T.: On the role of context in business process management. International Journal of Information Management 36, 486495 (2016)

12. McCormack, K., Willems, J., van den Bergh, J., Deschoolmeester, D., Willaert, P., Indihar Štemberger, M., Škrinjar, R., Trkman, P., Bronzo Ladeira, M., Paulo Valadares de Oliveira, M., et al.: A global investigation of key turning points in business process maturity. Business Process Mgmt Journal 15, 792-815 (2009)

13. de Bruin, T., Rosemann, M.: Using the Delphi technique to identify BPM capability areas. In: Proceedings of the Australasian Conference on Information Systems (2007)

14. Kerpedzhiev, G.D., König, U.M., Röglinger, M., Rosemann, M.: An Exploration into Future Business Process Management Capabilities in View of Digitalization. Bus Inf Syst Eng (2020)

15. van Looy, A., Poels, G., Snoeck, M.: Evaluating Business Process Maturity Models. JAIS 18, 461-486 (2017)

16. Lehnert, M., Linhart, A., Röglinger, M.: Value-based process project portfolio management: integrated planning of BPM capability development and process improvement. Bus Res 9, 377-419 (2016)

17. Vom Brocke, J., Schmiedel, T.: BPM - Driving Innovation in a Digital World. Springer International Publishing, Cham (2015)

18. Benner, M.J., Tushman, M.L.: Exploitation, Exploration, and Process Management: The Productivity Dilemma Revisited. AMR 28, 238-256 (2003)

19. Benner, M.J., Tushman, M.: Process Management and Technological Innovation: A Longitudinal Study of the Photography and Paint Industries. Administrative Science Quarterly 47, 676 (2002) 
20. Papadopoulos, T., Baltas, K.N., Balta, M.E.: The use of digital technologies by small and medium enterprises during COVID-19: Implications for theory and practice. International Journal of Information Management, 102192 (2020)

21. Doern, R., Williams, N., Vorley, T.: Special issue on entrepreneurship and crises: business as usual? An introduction and review of the literature. Entrepreneurship \& Regional Development 31, 400-412 (2019)

22. Martins, L.L., Rindova, V.P., Greenbaum, B.E.: Unlocking the Hidden Value of Concepts: A Cognitive Approach to Business Model Innovation. Strategic Entrepreneurship Journal 9, 99-117 (2015)

23. Verbeke, A.: Will the COVID-19 Pandemic Really Change the Governance of Global Value Chains? Brit J Manage 31, 444-446 (2020)

24. Trkman, P., Oliveira, M.P.V. de, McCormack, K.: Value-oriented supply chain risk management: you get what you expect. Industr Mngmnt \& Data Systems 116, 1061-1083 (2016)

25. Brynjolfsson, E., Horton, J., Ozimek, A., Rock, D., Sharma, G., TuYe, H.-Y.: COVID-19 and Remote Work: An Early Look at US Data. National Bureau of Economic Research, Cambridge, MA (2020)

26. Dwivedi, Y.K., Hughes, D.L., Coombs, C., Constantiou, I., Duan, Y., Edwards, J.S., Gupta, B., Lal, B., Misra, S., Prashant, P., et al.: Impact of COVID-19 pandemic on information management research and practice: Transforming education, work and life. International Journal of Information Management, 102211 (2020)

27. Linnenluecke, M.K.: Resilience in Business and Management Research: A Review of Influential Publications and a Research Agenda. International Journal of Management Reviews 19, 4-30 (2017)

28. Badakhshan, P., Conboy, K., Grisold, T., Vom Brocke, J.: Agile business process management. Business Process Mgmt Journal ahead-of-print (2019)

29. Venkatesh, V., Brown, S.A., Bala, H.: Bridging the Qualitative-Quantitative Divide: Guidelines for Conducting Mixed Methods Research in Information Systems. MISQ 37, 21-54 (2013)

30. Johnson, R.B., Onwuegbuzie, A.J., Turner, L.A.: Toward a Definition of Mixed Methods Research. Journal of Mixed Methods Research 1, 112-133 (2007)

31. Teddlie, C., Tashakkori, A.: Foundations of mixed methods research. Integrating quantitative and qualitative approaches in the social and behavioral sciences. SAGE Publ, Los Angeles (2010)

32. Etikan, I.: Comparison of Convenience Sampling and Purposive Sampling. AJTAS 5, 1 (2016)

33. Kaplan, B., Maxwell, J.A.: Qualitative Research Methods for Evaluating Computer Information Systems. In: Anderson, J.G., Aydin, C.E. (eds.) Evaluating the Organizational Impact of Healthcare Information Systems, pp. 30-55. Springer Science+Business Media Inc, New York, NY (2005)

34. Grimsley, M., Meehan, A.: e-Government information systems: Evaluation-led design for public value and client trust. European Journal of Information Systems $16,134-148$ (2007) 
35. Pinsonneault, A., Kraemer, K.: Survey Research Methodology in Management Information Systems: An Assessment. Journal of Management Information Systems 10, 75-105 (1993)

36. Schmiedel, T., Recker, J., Vom Brocke, J.: The relation between BPM culture, BPM methods, and process performance: Evidence from quantitative field studies. Information \& Management 57, 103175 (2020)

37. Urbach, N., Ahlemann, F.: Structural Equation Modeling in Information Systems Research Using Partial Least Squares. Journal of Information Technology Theory and Application 11 (2010)

38. Gable, G.G.: Integrating case study and survey research methods: an example in information systems. European Journal of Information Systems 3, 112-126 (1994) 